\title{
Abbreviations and glossary
}

$\begin{array}{ll}\text { BMUA } & \text { Belfast Metropolitan Urban Area } \\ \text { BNFC } & \begin{array}{l}\text { Belfast Naturalists' Field Club } \\ \text { Centre for Language and Communication Studies, Trinity } \\ \text { College, Dublin }\end{array} \\ \text { CSJNI } & \text { Campaign for Social Justice in Northern Ireland } \\ \text { CUD } & \text { Concise Ulster Dictionary } \\ \text { DENI } & \text { Department of Education, Northern Ireland } \\ \text { DUA } & \text { Derry Urban Area } \\ \text { H } & \text { 'High' language in a diglossic situation } \\ \text { HRT } & \text { High rising terminal } \\ \text { ICE-GB } & \text { International Corpus of English, Great Britain } \\ \text { ICE-IRL } & \text { International Corpus of English, Ireland (Northern Ireland } \\ & \text { and The Republic of Ireland) } \\ \text { IE } & \text { Irish English } \\ \text { IPA } & \text { International Phonetic Alphabet } \\ \text { L } & \text { 'Low' language in a diglossic situation } \\ \text { L1 } & \text { First language } \\ \text { L2 } & \text { Second language } \\ \text { LGD } & \text { Local Government District } \\ \text { LSS } & \text { Linguistic Survey of Scotland } \\ \text { MC } & \text { Middle class } \\ \text { MUE } & \text { Mid Ulster English } \\ \text { NFC } & \text { National Folklore Collection, University College } \\ & \text { Dublin } \\ \text { NI } & \text { Northern Ireland } \\ \text { NICEM } & \text { Northern Ireland Council for Ethnic Minorities } \\ \text { NIE } & \text { Northern Irish English } \\ \text { NISRA } & \text { Northern Ireland Statistics and Research Agency } \\ \text { NITCS } & \text { Northern Ireland Transcribed Corpus of Speech } \\ \text { NORM } & \text { Non-mobile, old rural male } \\ \text { NSR } & \text { Northern Subject Rule } \\ & \end{array}$


PRONI Public Records Office of Northern Ireland

QUB Queen's University, Belfast

Ramsar A Convention on Wetlands, signed in Ramsar, Iran, in 1971

ROI The Republic of Ireland

SED Survey of English Dialects

SPICE-IRL Systems of pragmatic annotation in the spoken component of the ICE-Ireland Corpus

SUE South Ulster English

SVLR Scottish Vowel Length Rule ('Aitken's Law')

TRSHE

URL Tape-Recorded Survey of Hiberno-English Speech

US Uniform resource locator

Ulster Scots 